\title{
ON HUMAN RIGHTS AND THE QUR'ANIC PERSPECTIVE: Freedom of Religion and the Rule of Apostasy
}

\section{Syafa'atun Almirzanah}

Faculty of Ushuluddin, Sunan Kalijaga State Islamic University Yogyakarta

\begin{abstract}
It is often argued that Islam is not compatible with modernity. This can be seen for instance in the fact of the problem that Islam faces to the challenge of universal values of human rights. Built on this supposition, the present article discusses on the great extent the question of religious freedom in Islam. As freedom of religion in the framework of universal declaration of human rights can mean as freedom to change religion, this contradicts to Islamic probibition of apostasy, punishable with death penalty. The author argues that Islam in fact guarantees religious freedom. This is clear from the Quranic injunctions assuring the freedom of choice whether to embrace Islam or not. Such a freedom is however often contradicted to one prophetic tradition sanctioning death penalty for apostasy. In her view, the author believes that the hadith more in attunes to the political strategy of the prophet to safe Muslim community from any acts of treason or sedition. Death penalty for apostasy is thus not related to the mere personal crime of changing religion but more that of public law related to war or crimes against state. More relying on the modern interpretation of the Quranic verses as well as the prophetic traditions, the author concludes that Islam is in conjunction with the modern values of religious freedom in which personal choice of religion or belief is the backbone of buman rights.
\end{abstract}

Keyword: Human right, freedom of religion, apostasy 
'Everyone has the right to freedom of thought, conscience and religion; this right includes freedom to change his religion of belief, and freedom, either alone or in community with others and in public or private, to manifest his religion or belief in teaching, practice, worship and observance."

\section{A. Introduction}

One of the challenges to the universality of human rights according to Michael Ignatieff arises from the resurgence of Islam. ${ }^{2}$ Indeed, the global resurgence of Islam since the seventies has been classified in the West under the monolithic category of religious fundamentalism. Following the collapse of the communist system, the West has viewed the phenomenon of Islamic revitalization primarily as a threat to its global interest. The subsequent stereotyping and demonization of Islam have continued to gain strength so that today Islam has become equated, in the West, with fanaticism, brutality, intolerance, violence, terrorism, despotism, violation of human rights, and obscurantism. The western media has only furthered these stereotypes.

Such perspectives of Islam might have also been exacerbated and influenced by Huntington's thesis of a 'clash of civilizations', that the next war will be between civilizations that is, between Islamic civilization and Western civilization.

One of the pressing issues today as scholars rethink and challenge narrow understanding of Islam, especially in so far as it concerns human rights, pluralism and interreligious dialogue, is freedom of religion, including conversion and rules of apostasy. Since the Declaration of human rights in 1945, the concept of freedom of religion has emerged as an essential part of international law. In the West, people think of the freedom to convert from one religion to another as a central guarantee of religious freedom. However, in Muslim milieus, a different perspective exists, so the question of whether there should be freedom to convert to another religion remains contested.

${ }^{1}$ Article 18 and 16 of UDHR, see twenty-four Human Right Doc, p. 8

2 See Michael Ignatieff, "The Attack on Human Rights", Foreign Affairs, November/December 2001, p. 102. 
It is historically significant that when the Declaration of Human Rights issued its proclamation on religious freedom, objections were raised by Saudi Arabia. The Saudi Arabian UN representative was particularly outspoken in criticizing this provision on the grounds that Islam did not permit Muslims to change their religion. ${ }^{3}$ This objection has been the basis for much subsequent research and argument concerning Islam and freedom of religion.

Contrary to the Saudi representative, a Pakistan representative to the UN voiced approval of the article in question. He spoke effectively in defense of the proposition, saying essentially, that freedom of religions as presented in that article was fully consonant with Islam. But, other Muslims disagreed with his opinion. Thus, there is still a serious point of conflict and tension within Islam over concepts of human rights as issued by the UN. The conservative Muslim opinion has been supported by state bans on conversion from Islam even with the possibility of the death penalty for apostasy, especially in Egypt. ${ }^{4}$ Although Islam fully recognizes the rights of individuals to practice the religion of their choice, apostasy (ridda) in traditional Muslim societies is strictly forbidden, even carrying the punishment of death. The right of a Muslim citizen to voluntarily renounce his or her religion is categorically denied. Changing religion as a matter of personal choice is prohibited and sanctions against apostasy appear to be so solidly established in the penal law that any conceivable change in this area seems unlikely.

Much also has been written about the relation of Islam and Islamic culture to Western notions regarding the organization of society and human rights. But the point of much of this writing is to demonstrate

${ }^{3}$ David Little, John Kelsay, and Abdulaziz Sachedina (eds.), Human Rights and the Conflict of Cultures: Western and Islamic Perspectives on Religious Liberty (Columbia: University of South Carolina Press, 1988), pp. 35-37.

${ }^{4}$ Since the 1970, there have been continuing demands in Egypt for a reinforcement of the death penalty for apostasy from Islam. Also the widely known 1994-1996 case of the Egyptian University professor Nasr Hamid Abū Zayd, who had to divorce his wife for his alleged apostasy, showed that Egypt's court were prepared to penaltize religious dissent in other ways. See Ann Elizabeth Mayer, Islam and Human Rights, Tradition and Politics, Third Edition (Colorado: Westview Press, 1999), p. 154. 
that Islam and the West are at the opposite poles concerning these important issues. In other words, these scholars argue that Islam is incompatible with the idea of human rights. Their main argument is that the provisions of the shari'a are in conflict with this concept and that these provisions continue to control the minds of Muslims. This view point is mainly derived from a monolithic perception of Islam, exclusively referring to radical Islam, especially its development in the Middle East.

Obviously, the monolithic framing of many Western observers which lends to misunderstand Islam is due largely to their limited knowledge of its nature. While it may be true that secular bias, as Esposito believes, ${ }^{5}$ has contributed to the failure of many non-Muslim scholars to understand Islam properly, the major pitfall lies in their ignorance of the fact that Islam is a polyinterpretable ${ }^{6}$ religion.

\section{B. Theoretical Frameworks}

What do I mean that Islam is polyinterpretable? Although Islam may appear to be monolithic, its form and expression vary from one Muslim individual to another and from group to group. Thus, there is no single interpretation for the Qur'an as the source of Islam. In addition, there is no concept of "church" in Islam and no one authority can issue a religious edict and expect it to be accepted universally by all Muslims. So how is Islam, especially shari' $a$ here to be understood?

There are a number of factors which can influence the outcome of an individual Muslim's understanding of the shari'a. Sociological, cultural and intellectual circumstances, or what Arkoun describes as the 'aesthetics of reception', certainly contribute to the forms and substances of interpretation. The 'aesthetic of reception' means, 'how a discourse, oral or written, is received by listeners or readers', especially, in the case of Islam and Muslims reception of the Qur'an. More specifically, it refers to the conditions of individual perception of each level of culture corresponding to a social group in every phase of

5 See,John L. Esposito, “Seculer Bias and Islamic Revivalism”, in The Chronicle of Higher Education, May 1993. 
historical development. ${ }^{7}$

Each Qur'anic verse produces an appropriate meaning according to the mode in which the interpreter understands it. According to Ibn 'Arabi, ${ }^{8}$ each word of the Qur'an -not to mention its verses and chapters -has an indefinite number of meanings, all of which are intended by God. Proper recitation of the Qur'an opens up the reader to new meanings at every reading. "When meaning repeats itself for someone reciting the Qur'an, he has not recited it as it should be recited. This is proof of his ignorance" And unless the text and its context are continually being reheard in the ever new texture, one is really not hearing what the text means. Rereading the scriptural sources themselves with a new eye is necessary.

Thus, no single scripture trajectory of any teaching should be absolutized and allowed to absorb the others. The evolutionary process

${ }^{6}$ A lengtly socio-historical discussion on this issue is found in, among other, Marshall. G. S. Hodgson, The Venture of Islam: Conscience and History in World Civilization, vol. I-III (Chicago: University of Chicago Press, 1974).

7 See, Arkoun, "The Concept of Authority in Islamic Thought", in Klauss Ferdinand and Mehdi Mozaffari (eds.), Islam: State and Society (London: Curzon Press, 1988), p. 58. In hermeneutics, inspired by Paul Ricoeur and Gadamer, each in his ways, we knew that reading text is not such a straightforward event. The text will disclose its meaning in interactive ways. Text means or produces meaning in many and different ways. In addition insight and enlightenment are provided in various contexts and by various peoples. Thus, everybody has his or her rights to understand the words he/she heard or read. He/she has his/her own reflection for the texts.

${ }^{8}$ His full name is Muhammad ibn 'A $\bar{T}$ ibn Muhammad ibn al-'Arabỉ al-Ṭá1 alHatimi, is a greatest Sufi Andalusia. He was born in Murcia, Andalusia, Spain on 17 Ramad̄an 560 H (July 28, 1165). One of the great miracles of career of our Great Master was his book. Osman Yahia, in the two volumes on the biography of Ibn al-'Arabi and the classification of his writings, accounted that Ibn al-'Arabi might have written 700 books, short articles, and collections of his poetry which 400 of them are available. The Meccan Revelation (Futühät al-Makkiyah) itself contains 17,000 of pages in Yahia's critical edition. The most scared by scholars is reading all Meccan Revelation, without mentioning others, either in the printed edition or manuscript. The problem has not been in the thickness of his book, but in its content which is difficult and demanding high understanding of Islamic knowledge. This help to understand why the Great Master (Shaykh al-Akbar), while his influence was world wide, but has been relatively forgotten

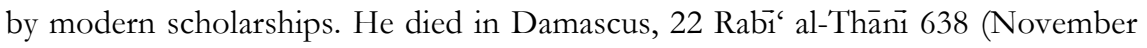
1240).

9 Ibn al-'Arabī, Futūhāt al-Makekiyah, vol. IV, p. 367. 
of interpretation that makes up the texts must continue today in the same manner in which it took place then, in continuity with what went before, preserving the past without embalming it, faithful to the past without being limited by it. We should be critically aware of the historical context in which Islam grew up when interpreting the doctrine. In other words, "faithfulness to principles cannot involve faithfulness to the historical model, because times change, societies and political and economic systems become more complex, and in every age it is in fact necessary to think of a model appropriate to each social and cultural reality." 10

Different intellectual inclinations also influence the effort to understand the Shari' $a$ and thus lead to different interpretations of a particular doctrine. Such inclinations can take the form of recovering the true meaning of the doctrine as literally expressed in the text, or finding general principles of doctrine beyond its literal or textual expression. Thus, while accepting the general principle of the shari' $a$, Muslims do not adhere to a single interpretation of it.

The emergence of a number of different schools of thought in Islamic jurisprudence and various theological and philosophical streams show that Islamic teachings are thus polyinterpretable. Throughout history the interpretable nature of Islam has functioned as the basis of Islamic flexibility. In addition, it also confirms the necessity of pluralism in Islamic tradition. Therefore, as many have argued, Islam can not and should not be perceived as monolithic. Thus Islam, as it actually exists and because of 'the divergence in the social, economic and political context' has meant different things to different people.

One also has to take into account the sociological influences while interpreting a divine scripture. No interpretation, however honest, can be free of such influence. The theologians and jurists of the first

${ }^{10}$ Tariq Ramadan, Western Muslims and the Future of Islam (Oxford: Oxford University Press, 2004), p. 36. In addition, says Ramadan, some religious commands related to the affairs of the world naturally take on the color of the culture of various countries: "the principle remains the same, but the ways of being faithful to them are diverse. So the concern should not be to dress as Prophet dressed but to dress according to the principles (of decency/politeness/morality/respectability, cleanness, simplicity, aesthetics, and modesty) that underlay his choice of clothes." 
century of Islam who acquired great prestige and whose opinions are taken as final in Muslim traditions were themselves not free from such influences. Their formulations and interpretations must be seen against the sociological perspective of their time, and cannot be seen apart from these limitations. Thus, any interpretation of scripture bears marks of the ethos of its own times.

Al-Ghazāly (d. 1111), known as b̧ujat al-Islām, asserts that sacred texts such as Qur'an and Hadith are open to interpretation on five different levels: (1) ontological-existential (dhäti), (2) experiential (hissi), (3) conceptual (khayyäli), (4) intellectual ('aqli), and (5) metaphorical $(\text { shabahi or majazi })^{11}$. Thus, everyone who interprets a statement of the text in accordance with one of the above levels of analysis has deemed such statements to be true. And anyone who engages in such interpretation, as long as he observes the rules of hermeneutics should not be branded as an unbeliever.

Nevertheless, all interpretations of a sacred text are not of equal value. Some may be misguided or even completely wrong. However, wrong interpretations should not be suppressed as heresy. An interpretation is heretical only if it denies the truth of a sacred text on all five hermeneutical levels above. Epistemologically, the exegesis of a sacred text constitutes informed opinion (zann) and not absolute truth (haqq), thus no one may claim an exclusive right of interpretation and no single interpretation is definitive. This approach helps not only preserve alternative voices that keep the process of interpretation open-ended, its spirit conforms to the liberal ideal of freedom of speech by granting to jurists and theologians the right to be wrong. The Qur'an, after all, is God's Speech; it is the self-disclosure of His infinite Essence. Diverse interpretations of the Qur'an answer to the diverse modes in which God discloses himself to the book's readers. To use Ibn 'Arabi's term, "The Qur'an is an ocean without shore". ${ }^{2}$

Shari'a, unlike the Qur'an, is full of human opinions. Correct knowledge of the history of Islam also indicates that shari' $a$ law developed centuries ago, and that, due to social and political

\footnotetext{
${ }^{11}$ See, Abū Hamidd Al-GhazāTi’s Faysal al-Tafriqa Bayna al-Islām wa'l-Zandaqa.

${ }^{12}$ Ibn al-Arabi, Futūhàt al-Makekiyah, vol. II, p. 581.
} 
circumstances, its stipulations have not been amended to accord with new social conditions. Thus we can say that the corpus of Shari' $a$ is a human construction, and some aspects of it may evolve just as human thought evolves and just as some aspect of the Qur'an and the Sunna were revealed over time. The Prophet says, "God sends to this community, every hundred years, someone to renew its religion." This renewal is not a modification of the sources but a transformation of the mind and eyes that read them, which are indeed naturally influenced by the new social, political, and scientific environment in which they live. It is for this reason that there are various schools of jurisprudence, which differ from one another on many questions. According to Abu Zayd, various schools of jurisprudence (al-madhähib al-Islämy) are nothing but the reflection of the evolution of life in the Islamic world, and these schools changed and evolved, transforming according to conditions of time and circumstance. ${ }^{13}$

Shari'a, as a human construction, is changeable, and many of its rules and regulations are not applicable to present social problems. Thus, the scholars should re-examine the shari' $a$ rules and regulations to adapt them to present social conditions. It is better to review the social conditions pertinent to a particular rule, and, if its application is no longer suitable, it should be replaced by a new rule inspired by Islam. ${ }^{14}$

Earlier Islamic thinkers, like Ibn Taymiyah, recognized the necessity for change in view of changing circumstances, and it is for this reason that he came out with a doctrine that religious edicts can change according to changing times. ${ }^{15}$ Even an orthodox thinker like him thought it necessary that ableam (edicts) should change with the

\footnotetext{
${ }^{13}$ Farrūq Abū Zayd, al-Shari'ah al-Islämiyah bayna al-Muhafiz̧in wa'- Mujaddidin (Cairo: n.d.), p. 16.

14 "Shari" $a$, which means 'the way to the source' is never confused with the source itself: the latter declares the absolute and the universal outside of time, but everything along the way must consider itself in time, in change, in imperfection, immersed in the reality of humankind — their rich humanity as well as their disturbing deceits. It really is a way toward the ideal, and anyone traveling along it is invited to make a constant effort to reform in the light of the universal, without ever claiming that one has attained the Truth of the universal. The three sources, the Text as well as the universe, teach one this humility; see Tariq Ramadan, Western, p. 37.
} 
change in historical and sociological circumstances. Thus we can say that 'in practice, the 'Way to faithfulness', teaches us that Islam rests on three sources: the Qur'an, the Sunna, and the state of the world, or of our society (al-wāqi $\left.{ }^{\prime}\right) . " 16$

The above perspective is based on the fact that the Koran was revealed to the Prophet over a period of 23 years. Some verses, therefore, refer to specific events like the campaign at the time of the battle Badr, and specific acts of the Prophet, such as his marriage to Zaynab bint Jahsh. (Q 33: 37). Moreover, various Qur'anic prescriptions relate to the practices of pre-Islamic society and were in response to the social circumstances prevalent then, and these practices no longer have the same social implications. Over the centuries, Muslims societies have changed and now have new problems which require new Shari'a legislation.

If we carry this argument a little further we can say that while the Qur'an was undoubtedly revealed for the whole of mankind and for all times to come, it contained that which had significance for the Arabs to whom it was revealed in order to be acceptable to them in their place and time. To be acceptable to the people to whom it is revealed, scripture must have immediate relevance for them. One might say scripture is contextually determined by their history, cultures and traditions. One cannot therefore deduce from verses in the Qur'an in isolation from their historical context as constitution or as legal code. It is for this reason that the principle of $i j t i b \bar{a} d^{17}$ was used right from the beginning. Ultimately, the denial of ijtibäd means nothing less than the denial of Allah continuing, living solicitude and the mission of the Prophet as a mercy to the world.

${ }^{15}$ Cited by Ashgar Ali Engineer, "Islam, Status of Women and Social Change", in Islam and the Modern Age, 1990, 21, 190.

${ }^{16}$ Tariq Ramadan, Western, p. 37.

${ }^{17}$ In general usage, the Arabic word ijtihäd denotes the utmost effort, physical or mental, expended in a particular activity. In its technical legal connotation, it denotes the thorough exertion of the jurist's mental faculty in finding a solution for a case of law. See, Wael B. Hallaq, 'Ijtihad', in John L. Esposito (ed.), The Oxford Encyclopedia of the Modern Islamic World, Vol. 2 (New York: Oxford University Press, 1995), p. 178. 


\section{Contemporary Implementation of Islam}

\section{Retbinking the Shari'a Rule on Apostasy}

Before I apply this interpretive framework to the question of the freedom of conversion discussed above, we must first determine more precisely what religious liberty is.

According to Muhammad Talbi, "religious liberty, in fact, is fundamentally the right to decide for oneself, without any kind of pressure, fear, or anxiety, whether to believe or not to believe, the right to pretend with full consciousness one's destiny, the right, of course, to discard every kind of faith as superstitious inherited from the dark Ages, but also the right to adopt the faith of one's choice, to worship, and to bear witnesses freely." in an Islamic state may be employed to compel people to embrace Islam." ${ }^{19}$

Religious liberty is the fundamental right of everyone. From a Muslim perspective, based on Qur'anic teaching, religious liberty is fundamentally an ultimate act of respect for God's sovereignty and for the mystery of God's plan for humanity. Ultimately, to respect human freedom is to respect God's plan. In short, to be a true Muslim is to submit to this plan.

Indeed, the Qur'an reminds us that not only was Adam created with rights, but the entire cosmological universe (the heaven and the earth) was similarly created with haqq, an Arabic term that can mean "right', "truth", or "justice". The idea that all created things posses rights that are part of their ontological nature is fundamental to the Islamic conception of justice. The Qur'an strongly guarantees all fundamental human rights. These rights are so deeply rooted in our humanness that their denial or violation is tantamount to a negation or

${ }^{18}$ Mohamed Talbi, "Religious Liberty: A Muslim Perspective", in Leonard Swidler (ed.), Religious Liberty and Human Rights in Nations and in Religions (Philadelphia: Ecumenical Press Temple University and New York: Hippocrene Books, 1986), p. 177. See also, Muhammad Talbi, "Religious Liberty", in Charles Kurzman, Liberal Islam, (Oxford: Oxford University Press, 1998), p. 162.

${ }^{19}$ Fatḥi 'Uthmān, Huqūq al-Insān bayn al-Shari'ah al-Islämiyyah wa'l-Fiker al-Qanūni al-Gharbì (Beirut: Dār al-Shurūq, 1401/1982), p. 97. 
degradation of that which makes us human.

The first and basic right emphasized by the Qur'an is the right to be regarded in a way that reflects the sanctity and absolute value of each human life. Each person has the right not only to life but also to respect, not by virtue of being a man or a woman, but by virtue of being a human being. The Qur'an states: "Verily, We have honored every human being"(17: 70). Following this right is the right of free choice, without which divine judgment would be meaningless: "The truth is from your Lord. So whosoever wishes shall believe, and whosoever wishes shall disbelieve" (18: 29). The idea of God's revelation of the truth and the human freedom to receive or refuse is crucial in the Islamic teaching on revelation and human responsibility. This has been seen as God's covenant to human beings since the beginning, ${ }^{20}$ in order that it is also the foundation of responsibility and the consequences of reward and punishment in the hereafter.

In addition, for faith to be true and reliable, it must be a voluntary act, born out of conviction and freedom, unfettered by pressure or coercion, and left to each individual to decide. So, compulsion and external interference would be the antithesis of Islamic faith. In fact, even the Prophet Muhammad was strongly admonished by God not to compel people to follow the truth of revelation. "If it had been thy Lord's will, they would all have believed all who are on earth! Wilt thou then compel mankind against their will to believe?" (10: 99). This text, revealed in Mecca, was later followed and confirmed, after the Prophet's migration to Medina, by the Qur'anic text which declares that "there is no compulsion in religion" (2: 256). ${ }^{21}$ The Prophet himself let a Christian, who was not sure about Islam, to keep his earlier belief and come back to his home safely. ${ }^{22}$ Thus, the principle

${ }^{20}$ See, the Qur'an, 7:172.

${ }^{21}$ This verse was used to reprove some Jews and Christians, newly converted to Islam in Madinah, who were willing to convert their children also to their new faith. It also has became the foundation for Christians who were forced to be Muslims to come back to their religion. And it is this principle of freedom of religion that has helped reserving and maintaining Eastern Christianity in the society dominated by Muslims. See, Mahmud Ayoub, "Islamic Context of Muslim Christian Relations", ICMR, 1992.

${ }^{22}$ See, Ismail Al-Faruqi, Islam and Other Faiths, edited by Attaullah Siddiqui (UK: The Islamic Foundation, 1998). 
of the freedom of conscience is firmly established in the Qur'an ${ }^{23}$ and the Sunnah.

As mentioned above, there seems to be a tension between the Islamic and the Western perspective on the matter of human rights. Since Islam is polyinterpretable, our discussion of Islam and religious liberty has to begin with the stipulation that a dialogical approach requires a greater appreciation of the statement of Muslims themselves on matters of human rights.

It's worth to mention that for more than a hundred years, Muslims have argued that Islamic law can and must be revised and reinterpreted in order to adapt it to present-day needs. Thus, Islam and an adherence to Islamic law do not, in themselves, pose an obstacle to the enforcement of human rights principles.

An-Na'im argues that the provisions regarding slavery and discrimination on grounds of gender and religion in Shari' a must be abolished. While traditionally such practices were the norms, these aspects of public law of Shari' $a$ are today fundamentally inconsistent with the realities of modern life. ${ }^{24}$ He states that the aspect of the Shari' $a$ that violates freedom of religion and conscience as a human right is the notion of apostasy. Besides its obvious discrimination against non-Muslims, this principle also violates the freedom of belief and expression of Muslims themselves. ${ }^{25}$ In order to resolve the human

${ }^{23}$ In spite of the relative clearness of the Qur'anic assertion of the freedom of religion, the subject has become controversial due to certain other passages in the Qur'an which have sometimes been interpreted in a manner which casts doubt on the subject. Some commentators, motivated by political discourses have concluded that the Qur'anic verses which validate jihad and fighting against disbelievers actually abrogate the Qur'an's proclamation on tolerance and respect for other religions. See, Muhammad Hashim Kamali, Freedom of Expression in Islam (Cambridge: Islamic Texts Society, 1997); cf. Abdullahi Ahmed An-Na'im, "The Islamic law of Apostasy and Its Modern Applicability, A Case from Sudan," Religion, 1996, pp. 16, 197-224.

${ }^{24}$ Abdullahi Ahmed An-Na'im, Toward an Islamic Reformation, Civil Liberties, Human Rights and International Law (New York: Syracuse University Press, 1990), pp. 175177.

${ }^{25}$ Abdullahi Ahmed An-Na'im, "Qur'an, Shari'a and Human Rights: Foundations, Deficiencies and Prospects", in Concillium, no. 2, 1990, p. 64 and AnNai'm, Toward an Islamic, pp. 183-184. 
rights problem related directly or indirectly to the above noted principle of Shari'a, a drastic Islamic reform is urgently needed. ${ }^{26}$ He gives an appropriate methodology of reform, i.e., an appreciation of the impact of historical context on interpretation of sources of Islam. If early Muslims were able to interpret the Qur'an and other sources according to their context, contemporary Muslims should be able to undertake a similar process of interpretation and application of the Qur'an and other sources in the present time. Throughout its history, the understanding and implementation of Islam have been influenced by the social and political realities of Muslim communities. While AnNa'im believes that Qur'an is divine, he also believes that there is no way of implementing divine texts without the intervention of human agency in terms of both interpretation and application. ${ }^{27}$

Historical precedents for reform in Shari'a conceptioning apostasy already exist. Many thoughtful Muslims in the past were prepared to reform, even to discard, the pre-modern Islamic jurisprudence of the apostasy penalty and accept the concept of religious freedom. ${ }^{28}$ Thus, contemporary Muslims who have denied the penalty argue that traditional pre-modern juristic interpretations were unwarranted by Islamic sources and out of keeping with the principle that there is "no compulsion in religion" (the Qur'an 2: 256). ${ }^{29}$

If we go by the Qur'an, we also can find that there is no verse in the Qur'an that requires any earthly penalty for apostasy and that the rule of apostasy applied by traditionalist jurists were inferred from incidents in the Prophet's life and from historical events after his death

${ }^{26} \mathrm{He}$ asserts that shari' $a$ is not divine because it is the product of human interpretation of the divine sources of Islam, that is the Qur'an and the Sunnah. Moreover, this process of construction through human interpretation took place within a specific historical context which is dramatically different from our own. See, Al-Nai'm, "Shari" $a$ and Basic Human Rights Concerns", in Charles Kurzman, Liberal Islam, (Oxford: Oxford University Press, 1998), p. 237.

${ }^{27}$ An-Na'im, "Qur'an, Shari'a", p. 67; see also An-Na'im, Toward an Islamic, pp. 185-186.

${ }^{28}$ See for example the commentary of Mahmud Shaltut on verse of the Qur'an 26: 4 in Mahmud Shaltut, Al-Isläm 'Aqidah wa-Shari'ah, $2^{\text {nd }}$ ed., (Cairo: n.d.), p. 33.

${ }^{29}$ See Muhammad Talbi, "Religious Liberty: A Muslim Perspective” in Swidler, Religious Liberty, pp. 175- 188. 
that actually lend them to the multiplicity of interpretation. A rethinking of the Islamic tradition in the light of modern concerns and needs leads to the conclusion that the Qur'anic principle of religious liberty shares common foundations with the Western concept of religious liberty.

Contemporary scholars have found many reasons for rethinking the jurists' ruling that an apostate must be executed. They argued that it is not in line with the spirit of Islam. According to them, time and circumstances have changed significantly and this should be taken into account when dealing with the problem. An Egyptian modernist Muslim scholar, Mạ̣mūd Shalțūt, Shaykh al-Azhar (d. 1963), argued that the death penalty in early Islamic history was really a punishment for crimes against the state. Furthermore, he said that the punishment for apostasy is really based on isolated hadith (badith ăbăd) and that budüd cannot be established on such a foundation. For Shaltut, unbelief alone is not a justification for punishment. ${ }^{30}$

Mahmoud Ayoub, in "Religious Freedom and the Law of Apostasy in Islam" said that the Qur'an treats the problem of apostasy in the context of faith and the rejection of faith. In this context, "apostasy is a religious and moral decision subject to divine retribution or pardon on the Day of Judgment. Apostasy is, therefore, a personal inner moral decision, ultimately lying outside the jurisdiction of the sacred law." ${ }^{31}$ In the past, apostasy was never a problem for the Muslim communities. To a great extent, it remained a theoretical issue because the people executed for apostasy until the end of the Abbasid caliphate in the thirteenth century were few in number. ${ }^{32}$

The Lebanese scholar, Subhi Mahmassani, affirms that the punishment of death does not apply to apostasy per se. And the facts accompanying to the application of the penalty were intended to be narrow. He points out that the Prophet never killed anyone purely for

${ }^{30}$ Mahmud Shaltut, Al-Islām: 'Aqidah wa-Sharì'ah (Kuwait: Dār al-Qalām, n. d.), pp. 292-3, quoted by Abdullah Saeed and Hassan Saeed, Freedom of Religion, Apostasy and Islam (Ashgate, 2004), p. 95.

${ }^{31}$ Mahmoud Ayoub, "Religious Freedom and the Law of Apostasy in Islam", Islamochristiana 20, 1994, p. 78.

${ }^{32}$ Ayoub, "Religious Freedom", p. 90. 
apostasy alone. Indeed, the death penalty was applied when the act of apostasy from Islam was linked to an act of political betrayal of the community. This being the case, Mahmassani argues that the death penalty was not meant to apply to a simple act of renunciation of faith, but to punish acts such as high treason, joining forces with the enemy, and sedition. ${ }^{33}$ Muhammad Talbi ${ }^{34}$ said that in this field a traditional theology did not follow the spirit of the Qur'an; on the contrary, it seriously abridged the liberty of choice of one's religion. According to this theology, although conversion to Islam must be, and is in fact, without coercion, it is practically impossible, once inside Islam, to get out of it. And according to this understanding, "conversion from Islam to another religion is considered treason, and thus the apostate is liable to the penalty of death." 35

The elaboration of traditional theologians relies on the precedent of the first caliph of Islam, Abu Bakr (632-634. C.E.) who aggressively fought the tribes that rejected his authority after the Prophet's death and refused to collect zakāt, comparing their rebellion to apostasy. ${ }^{36}$

${ }^{33}$ Ṣubḥi Mạ̣maṣsanì, Arkēn Huqūq al-Insān (Beirut: Dār al-'Ilm li'l-Malāyin, 1979), pp. 123-124.

${ }^{34}$ See Leonard Swidler, Religious Liberty, p. 182.

${ }^{35}$ See, Abd al-Raḥmān al-Ghazari, Al-Fiqh 'alàl-Madhähib al-Arba' ab (Beirut, 1972), vol. 5, pp. 422-426.

${ }^{36} \mathrm{Abu}$ Bakr's decision not to negotiate and later to fight against those who refused to pay zakat was met a strong objections from a number of other Companions, especially 'Umar ibn al-Khațāa (d. 23/644) who felt that the caliph did not have he authority to fight other Muslims. 'Umar argued that, because these people were indeed Muslims, as was indicated by the fact that they declared that there was no God but Allah and that Muhammad was the messenger of Allah, and performed the prayers, there were no legal grounds for Abu Bakr to take up arms against them. This is because for 'Umar paying zakāt to the central authority was not as important as it was for Abū Bakr. For the latter, however, the matter was not so simple; in addition to being a religious obligation, the survival of the central authority of Medina depended in some respect on the payment of zakāt. This was primarily a political and financial issue, rather than the religious issue which later jurists and historians made it out to be. It was Abū Bakr's political insight as well his strategic thinking that led him to fight for survival. Thus, the battles that Abu Bakr fought were not religious; they were largely political, waged to sustain the central authority of Medina and protect the community and institutions the Prophet had established. See, Abdullah Saeed and Hassan Saeed, Freedom of Religion, Apostasy and Islam (Ashgate, 2004), p. 66. 
They also rely on the authority of the hadith ${ }^{37}$ that "Anyone who changes his religion must be put to death." 38

Interestingly, a close review of the context in which these references occur, however, reveals that the only allowable use of force is for purposes of defense not for coercion. It also refers to a Muslim who deserts his fellows and joins the enemies of Islam. Thus, it refers to alienation from the Muslim community, and to rebelling and fighting against community. The punishment is meant for whom repudiate Islam and then join the enemy and actively hostile to the Muslim community or seek to disrupt the social order. It also means, that if non-Muslims instigate the use of force for the purpose of military conquest or religious persecution, or through the breach of a solemn treaty, then forceful reaction is justifiable. These passages justify force as a response to persecution and the threat of destruction. Underlying this justification is an appeal to basic moral requirements - either to keep promises and treaties, or to protect some communities' basic welfare and security against aggression. So construed, these injunctions to use force against unbelievers and apostates are grounded in emergency conditions, which consist of moral rather than religious provocation. Thus, it is not fundamentally because unbelievers hold the beliefs they do, but because of their manifest moral violations that they are liable to punishment and coercion. It also can be said that the incidence was a political issue, rather than the religious one.

The approach above is consonant with Fazlurrahman's opinion that the aim of Islamic ideology, as it expressed in the Qur'an, is to create a just society, to "command good and forbid evil." ${ }^{39}$ This ideology is presupposed behind each principle of the Qur'an. The ḥadith mentioned above, upon which the penalty of death essentially rests, is always more or less involved with rebellion and highway robbery in the traditional sources. The incidences during the Prophet's life or soon

${ }^{37}$ Hadith is a term applied to specific reports of the Prophet Muhammad's words and deeds as well as those of many of the early Muslims. See, R. Marston Speight, 'Hadith' in John L. Esposito, The Oxford Encyclopedia, p. 83.

${ }^{38}$ For this ḥadith see, e.g., Al-Bukhārì, Saḥịh, (Cairo: ed. Al-Sa'b, n.d.), vol. VIII, pp. 201-2, and vol. ix, pp. 18-20.

${ }^{39}$ Qur'an, 3: 104 and 110; 9: 71. 
after his death during the regime of the four Rightly-Guided Caliphs on which capital punishment for apostasy in part rests, are the illustrations of requital for active hostility or social disruption to the community; they are persons who, as a result of their apostasy turned their weapons against the Muslims, whose community at that time was still small and vulnerable. ${ }^{40}$ In these circumstances the penalty of death seems to be an act of self - defense in a war situation. Furthermore, the hadith justifying the death penalty is an isolated hadith (badith $\bar{a} \bar{a} \bar{a} d$ ) and not, technically mutawatir ${ }^{41}$, and consequently it is not binding. In any case, this hadith is at variance with the teaching of the Qur'an, where there is absolutely no mention of a required death penalty against the apostate.

What is needed for a new understanding is to transcend our apparently limiting sociological and historical necessity. We are often unaware of the extent to which we are bound by sociological, cultural and historical circumstances, and the consequent resoluteness and conviction with which we uphold received interpretation of the Qur'an. It seems to us that we are bound by a sociological determinism that makes us intolerant and disrespectful to others, and thus unable to support religious liberty. Indeed, negative confrontation, such as that mentioned at the beginning of this paper, relating to the freedom of religion, could be avoided if we could transcend ourselves from the experiential limits of our social and cultural circumstances. Concerning conversion, for example, if the Saudi Arabian representative could have transcended his socio-cultural experience, he would have asked himself why Islam imposes the death penalty on someone who converts from Islam to another religion, seeing that this penalty is at the level of figh, not at the level of the Qur'an. There is no injunction in the Qur'an on penalty or punishment. That standard is available in the Qur'an, but an edict that the convert must be killed is only in the fiqh, which is polyinterpretable. For this reason one-way to create further understanding and strengthen interreligious relations is to return to

${ }^{40}$ See, Muhammad Talbi "Religious Liberty”, in Leonard Swidler (ed), Religious Liberty and Human Rights (Temple University: Ecumenical Press, 1986), p. 183.

${ }^{41} A$ ḅadith is called mutawatir when it is transmitted uninterrupted through a chain of widely believed to the reliable warrantors. 
the Qur'an itself. Only then, can we transcend our socio-cultural, sociohistorical even socio-psychological necessity. This was fully consonant with the actions of Umar, a second caliphate, when faced with the death of the Prophet Muhammad; he had the courage to say, "the Qur'an is enough for us". Iqbal as well is opinioned that the Qur'an has been the ultimate source for Islamic consideration. ${ }^{42}$

To recapitulate, the Qur'an mentions no penalty for conversion. Or we can say that there is no specified hadd in this matter. On the contrary, Muslims are advised to "forgive and over look till God accomplished this purpose, for God hath power over all things." ${ }^{33}$ Today, Muslims are not obliged to impose the death penalty for the apostate. There is no clear text in the Qur'an to support this penalty. There are also plentiful grounds for determining that the juristic rules on apostasy no longer apply. Muslim can identify many alternative interpretations of the Qur'an consistent with modern ideas of religious freedom. ${ }^{44}$

The Muslim jurist, who is taught to consider a scriptural obligation as prior to a moral duty, must review each obligation according to whether the divine command that governs it is general or specific in its application. If the application is specific, he must make inquiries about any limitations to its application that might arise through the historical context of its revelation. A divine command must not be applied universally if the context of its revelation demonstrates conclusively that its application is specific to a particular time, place, or social situation. It might also be considered that a moratorium be placed on a certain rule if non-suitable conditions exist for its implementation. It is based on the basic élan of the Qur'an, that is, moral and followed by social and economic justice.

There are instances which demonstrate that the same shari' $a$ rule was applied variously at different times and in different societies, and even the Qur'anic stipulations and traditions of the Prophet have often been suspended. The changeability of Islamic law for example can be

${ }^{42}$ Muhammad Iqbal, The Reconstruction of Religious Thought in Islam (Lahore: Sh. Muhammad Ashraf, 1968), p. 168.

${ }^{43}$ Qur'an, II: 109

${ }^{44} \mathrm{In}$ fact, there is no unanimous agreement among the jurist on the issue. 
seen in the punishment for the consumption of alcohol. Although the Qur'an does not stipulate any punishment for the consumption of alcohol, during the Prophet's lifetime a person who committed this offence was beaten, and although the Rightly-Guided Caliphs were guided by the Qur'an and their immediate knowledge of the teaching of the Prophet, they nonetheless exceeded the punishment stipulated by the tradition of the Prophet. Abu Bakr stipulated whipping the offender with forty lashes, and Umar b. al-Khattab increased this to sixty lashes. The later also abolished temporary marriage (Mut'a) that had been an accepted Islamic marriage contract.

Another example showing how the Qur'an is contextual is the case of bijäb, in which the Qur'an uses the term in a different way. In the Qur'an, the word occurs in the Meccan period to mean that the unbelievers are separated from God (83: 14), and to refer to the fact that when Maryam found that she was pregnant she lived in seclusion (19: 15-16). The word bijäb was used only once in the Medina period (33: 7), where it refers only to the wives of the Prophet, to whom men should speak from behind a curtain. The debate on the subject of veiling women focuses on Sura 33: 59 and 24: 31 which specially refers to the wives of the Prophet and to the women of the believers respectively, each with its context. Sura 33: 59 says: "O Prophet, say to the wives and daughters and the believing women that they draw their veils close to them, so it is more likely that they would be known and not hurt." The historical circumstance of this verse was directed against the youth who followed women when they left their compound at night to go to the outskirts of Medina. Slave women who were available to men used to be dressed as free women, so the Qur'anic verse recommends the veiling of the wives of the Prophet so that they would then be distinguished and not hurt. The command of Sura 24: 31 refers to the fact that women used to wear shirts which had a large opening below the neck and showed their breasts while their headcovering fell on their shoulders. Thus they were advised to draw their head-coverings over their front to cover their breasts. These Qur'anic verses advise, but do not stipulate any punishment - either in this world or in the hereafter. 
It is unfortunate that, Muslim reformers who wish to reform their societies by making Shari' $a$ the basis of their legal systems often forget that the duty of mercy applies to each and every obligation that is enjoined upon human beings in the Qur'an. What this means in practice is that when the performance of an obligation calls for severity (harshness), it is the duty of Muslims to temper severity with mercy. Among Allah's own names are Rahmān and Rahim (compassionate and merciful). A Muslim begins everything by reciting Bi'-smi'l-lähi'rrabmanir-rabim (i.e. in the name of Allah Who is Compassionate and Merciful). Thus a Muslim is supposed to invoke Allah the Compassionate and Merciful at every step. In fact, Allah sent His Messenger Muhammad also as the Mercy of the World "And We have sent you not but as a mercy for all that exist" (21:107). Thus the Prophet of Islam represents universal mercy. As the Messenger of Allah, he is representative of His Mercy and hence the Prophet himself is known as rahmah li'-'alamin (mercy of the worlds). Thus a true follower of the Prophet has to be merciful and compassionate to the extent humanly possible.

A real Muslim is one who despite being firm in his/her faith tradition shows equal love and compassion for all human beings whether they belong to his faith tradition or not. Every faith tradition is unique and should be recognized as such but it should not become a tool of discrimination. The Qur'an itself declares that all human beings, all children of Adam have been honored equally (17:70). Thus there is no justification in showing any discrimination on the basis of faith as far as the Qur'an is concerned.

Unlike sufis, who preferred to trust in God's mercy and forgiveness, the jurists were more likely to trust in His wrath and vengeance. The jurists had much to do with their chosen role as guardians of religious and social order. They appealed to God who will punish all those who stray from the straight and narrow. We may better to be like the Sufis who called upon a God who loves his creatures and inclines to forgive all sins. 


\section{BIBLIOGRAPHY}

'Arabi, Ibn, al-' Futūhat al-Makiyyah.

Arkoun, Mohamed, "The Concept of Authority in Islamic Thought", in Klauss Ferdinand and Mehdi Mozaffari (eds.), Islam: State and Society, London: Curzon Press, 1988.

Ayoub, Mahmoud, "Religious Freedom and the Law of Apostasy in Islam”, Islamochristiana 20, 1994.

—, "Islamic Context of Muslim Christian Relations", ICMR, 1992.

Al-Bukhārì, Șahīḥ, Cairo: ed. Al-Sa’b, n.d.

Dāwud, 'Abū, Sunan, Cairo, 1952.

Engineer, Ashgar Ali, "Islam, Status of Women and Social Change", in Islam and the Modern Age, 1990.

Esposito, John L., "Secular Bias and Islamic Revivalism", in The Chronicle of Higher Education, May 1993.

Al-Faruqi, Ismail, Islam and Other Faiths, edited by Attaullah Siddiqui, UK: The Islamic Foundation, 1998.

Al-Ghazāil, Abū Hamid, Fayșal al-Tafriqa bayna al-Islām wa'-Zandaqa.

Al-Ghazari, 'Abd al-Raḥmān al-, Al-Fiqh 'alà al-Madhābib al-Arba'ah, Beirut, 1972.

Hallaq, Wael B., "Ijtihad", in John L. Esposito, ed., The Oxford Encyclopedia of the Modern Islamic World, Vol. 2, New York: Oxford University Press, 1995.

Hodgson, Marshall. G. S., The Venture of Islam: Conscience and History in World Civilization, vol. I-III, Chicago: University of Chicago Press, 1974.

Ignatieff, Michael, "The Attack on Human Rights", Foreign Affairs, November/December 2001.

Iqbal, Muhammad, The Reconstruction of Religious Thought in Islam, Lahore: Sh. Muhammad Ashraf, 1968.

Kamali, Muhammad Hashim, Freedom of Expression in Islam, Cambridge: Islamic Texts Society, 1997. 
Little, David, John Kelsay, and Abdulaziz Sachedina (eds.), Human Rights and the Conflict of Cultures: Western and Islamic Perspectives on Religious Liberty, Columbia: University of South Carolina Press, 1988.

Mayer, Ann Elizabeth, Islam and Human Rights, Tradition and Politics, Third Edition, Colorado: Westview Press, 1999.

An-Na'im, Abdullahi Ahmed an-, "Qur'an, Shari' $a$ and Human Rights: Foundations, Deficiencies and Prospects", in Concillium, no. 2, 1990.

—, "The Islamic law of Apostasy and Its Modern Applicability, A Case from Sudan," Religion, 1996.

-, Toward an Islamic Reformation, Civil Liberties, Human Rights and International Law, New York: Syracuse University Press, 1990.

Ramadan, Tariq, Western Muslims and the Future of Islam, Oxford: Oxford University Press, 2004.

Șubḥi Mạ̣mașșani, Arkān Huqūq al-Insān, Beirut: Dār al-'Ilm li'lMalāyin, 1979.

Saeed, Abdullah and Hassan Saeed, Freedom of Religion, Apostasy and Islam, Ashgate, 2004.

Speight, R. Marston, "Hadith", in John L. Esposito, The Oxford Encyclopedia.

Talbi, Mohamed, "Religious Liberty: A Muslim Perspective", in Leonard Swidler (ed.), Religious Liberty and Human Rights in Nations and in Religions, Philadelphia: Ecumenical Press Temple University and New York: Hippocrene Books, 1986.

Talbi, Muhammad, "Religious Liberty", in Charles Kurzman, Liberal Islam, Oxford University Press, 1998.

'Uthmān, Fathi, Huqūq al-Insān bayn al-Shari'ah al-Islämiyah wa'l-Fiker alQanūni al-Gharbi, Beirut: Dār al-Shurūq, 1401/1982.

Zayd, Farrūq Abū, Al-Shari'ah al-Islämiyah baina al-Mụ̣afiżin wa'lMujaddidin, Cairo: n.d. 